\title{
Data-mining case tests boundaries of medical privacy
}

$\mathrm{H}$ ippocrates' ancient oath to keep secrets sacred between physician and patient is having a rough time of it in the modern age as drug companies, governments and insurers dip into databases rich with personal medical information.

Just how accessible these records should be is a question coming before the United States Supreme Court.

The high court will decide whether and under what circumstances the government can prohibit private interests from tapping into vast prescription records and using the material to market drugs.

The case, to be heard Apr. 26, has potentially profound implications for the nation and beyond. Technology is bringing mountains of personal information within reach of those who want it, straining safeguards against abuse and shifting the line between what is permissible and not.

The court will examine whether one broad and contentious front of information-sharing, prescription "data-mining," violates privacy or whether restricting the practice would be an unconstitutional attack on free speech.

If the scales of justice were tipped by the sheer number of parties on one side of the case, it would be a slam dunk against the data miners and drug industry (www.scotusblog.com/case-files/cases /sorrell-v-ims-health-inc).

Tiny Vermont, the state taking the case to the Supreme Court, is supported by the US government, three dozen other states, various medical societies and, of course, privacy advocates.

But they have a high hurdle to clear. Justices on the court, both conservative and liberal, have taken an expansive view of what constitutes protected speech under the US Constitution's First Amendment. The question becomes whether collecting and selling prescription information counts as free speech in the eyes of the court.

Privacy advocates hope not.

The court voted 8-1 in March in

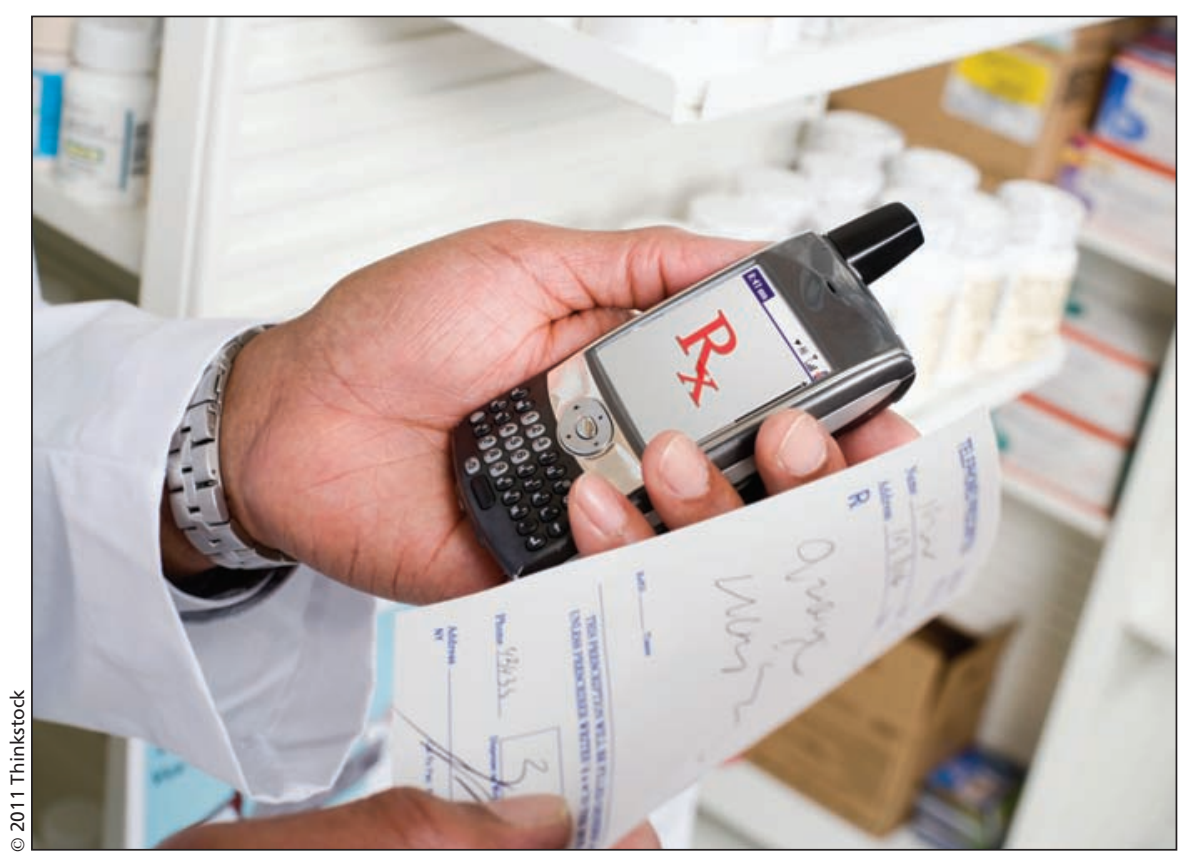

Pharmacies in the United States typically sell select data about patients and their prescriptions to companies that aggregate and resell the information to drug makers, law enforcement agencies and researchers.

favour of a fundamentalist church's right to stage mocking protests at family funerals of soldiers, during which protestors held signs saying: "Thank God for dead soldiers." The court also has invalidated laws to protect children from online porn, reversed a century's trend to limit the political influence of businesses and unions, and struck down a law banning the online display of graphic violence against animals - all in the name of the First Amendment.

Against that backdrop, swapping drug information might not seem so radical.

In the case at hand, Vermont wants the high court to reinstate its 2007 law restricting prescription data-mining, which a lower court overturned. Other courts upheld similar laws in Maine and New Hampshire. Altogether, more than 20 states are in various stages of legislating controls on the use of prescription data - all now hanging in the balance.

By law, when US doctors write a prescription, a record is built of their names; the patient's name, address, sex, and birth year; the name, strength and dosage of prescribed drugs; and more. Pharmacies sell these details - minus the patient's name and exact address to companies that aggregate and resell the data to drug makers, law enforcement agencies and researchers.

This enables drug marketers to tailor sales pitches at individual doctors.

Vermont's law only curbs commercial end-use of the information and bars its use unless doctors consent. But the Pharmaceutical Research and Manufacturers of America argues in its Supreme Court petition that the law unfairly restricts the industry from using information that remains available to others. "Medical privacy is a blatant pretext that fails to mask the overt discrimination against one message (prescription drug marketing) and one set of participants in the marketplace of ideas (pharmaceutical manufacturers)," the group asserts.

Vermont counters that the efficacy of the marketing is such that health care costs are swelling as doctors prescribe brand-name drugs when generics would do. The industry, though, 
argues that it's a vital marketing tool for companies that spend fortunes developing new therapies only to have cheap generics upend their profits down the road.

In their Supreme Court petition, Vermont officials report that many doctors were unaware their prescribing information was being sold and used to monitor their physician-patient relationships.

"Doctors found the practice 'outrageous' and 'demeaning,' considered pharmaceutical companies to be 'spying' on doctors, and felt as though the sales representatives had information as sensitive as a bank account number," Vermont Attorney General William H. Sorrell contends.

But what's the harm to anonymous patients?

Marc Rotenberg, executive director of the Electronic Privacy Information Center, says the cryptographic technique used to protect patient identity is outdated. Anonymity, he says, cannot be assured when the personal information that is retained in prescription records is combined with identifiers in other databases - a user's online search queries, credit card records, even movie reviews. The industry disputes that.

Privacy advocates have armed themselves with the Hippocratic Oath and its vow to "respect the privacy of my patients, for their problems are not disclosed to me that the world may know," as one version has it.

That oath, though, has been amended over centuries to keep it relevant to changing times. Nine justices will decide in some fashion what it means now. - Cal Woodward, Washington, DC

CMAJ 2011. DOI:10.1503/cmaj.109-3853 